\section{Willing Hands and Hearts: The Rebuilding of the Royal University of Cambodia}

\section{Pit Chamnan}

Pit Chamnan is rector of the Royal University of Phnom Penh. Address: Royal University of Phnom Penh, Pochentong Road, Phnom Penh, Cambodia.

$\mathrm{T}$ he Royal University of Phnom Penh, formerly Khmer Royal University, was founded in January 1960, with a Faculty of Letters and Humanities and a Faculty of Science and Technology. The language of instruction was French. The university closed in 1975; between 1975 and 1979 , under a regime that targeted the educated, most of its faculty were killed. Of those who survived, few remained once the borders opened. Deserted for almost five years, the campus became another victim of the grim civil war.

In 1981, the university reopened as a teacher training college and a foreign language institute (FLI). The purpose of both was to provide surviving graduates of primary school (grades 1 to 5) or above with crash training as teachers. In 1988, the college and the FLI merged to create Phnom Penh University, later the Royal University of Phnom Penh. In the past decade the university has grown and now includes the faculties of social science and humanities (history, sociology, philosophy, geography, psychology and Khmer literature); science (mathematics, chemistry, biology, physics, and computer science); and foreign languages (English and French).

\section{Between 1975 and 1979, under a re- gime that targeted the educated, most of [the university's] faculty were killed.}

In the undergraduate program the primary language of instruction is Khmer, although some courses are taught in French and all students are required to take three years of English or French. The university has a new library, donated by Prime Minister Hun Sen. Although only four years old, the library is already too small. Over 600 students a day use the one-floor building. The library has over 26,000 books in Khmer, French, and English, donated by embassies and foundations. The process of translating basic science texts into Khmer has been slow, in part because faculty lack adequate background in the subject matter.

The laboratory facilities in physics, biology, chemistry, and environmental studies have been reestablished more slowly. While faculty training is an issue, poor facilities and equipment play a role. Last summer with the help of Irish volunteers a successful program was offered in lab management and experiments for high school science teachers. The university also has a computer center to serve university and departmental needs. Faculty and students also have access to the Internet through the library and the career/ academic counseling office.

The University of Technology Sydney, in Australia, assisted the Royal University of Phnom Penh by providing hardware initially and helping the registrar's office to design a software program for student records and transcripts. A locally based nongovernmental organization provided additional equipment and ongoing support.

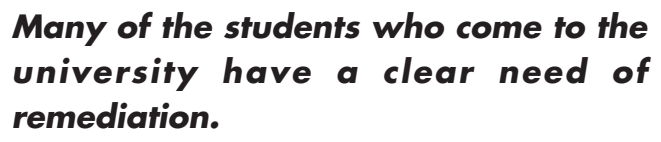

The teaching staff is made up of 200 persons, 12 with Ph.Ds, 20 with master's degrees, and the remainder with undergraduate teaching degrees from Phnom Penh University. In addition, various international and nongovernment institutions as well as some private groups provide adjunct faculty, who not only teach but often serve as peer mentors. The need for faculty upgrading is both obvious and urgent. The faculty development plan stresses graduate degrees and general improvement of content and teaching methodology. Unfortunately, since government and donor support has not been available for faculty development progress is slow and erratic.

Although the teaching staff seems large relative to the enrollment, with 1 faculty member for every 4.5 students, most staff are not full-time. The average civil service salary, including that of primary teachers and university faculty, is U.S.\$20 per month. This is only about 25 percent of the World Bank estimate of the salary for a family of five living below the poverty line. In real terms, this means that even faculty who do get extra teaching hours must scramble to support their families. There are also about 176 administrative and support staff spread across three campuses. These staff must contend with the same training needs and salary issues as the teaching faculty.

Students are admitted to the university through a series of national entrance examinations held annually by the Ministry of Education, Youth, and Sport. Enrollments for the 1998-1999 academic year totaled 4,577, of which only 23 percent were women, reflecting the fact that throughout the primary and secondary subsystems the enrollment and retention of girls remain a serious problem. Many of 
the students who come to the university have a clear need of remediation. Outside of Phnom Penh and other major urban areas few schools have libraries, much less laboratories. In addition, most students from the countryside have had little exposure to foreign languages. Thus, as the university moves toward a credit unit system, it is likely that somewhere near 155 credit units will be required for graduation rather than on average 120 units required in the United States.

Within the context of sharply constrained national resources and the lack of large donors, the resource issues have been persistent. To help solve them, government has recently granted the university permission to charge tuition. It is hoped these funds will be used to enhance academic quality through the rationalization and upgrading of staff and further program development.

In a country where up to 90 percent of the educated population were killed, we have a long way to go to produce graduates with the dedication and skills needed to guide Cambodia into a secure future. But we have also come a long way. The university has been reestablished. Improvements, even if small incrementally, have a large cumulative effect. Growth has been constant: enrollments and program offerings have increased, library and laboratories reopened, faculty and staff given short-term training, and a few sent for higher academic degrees. This progress is in large measure owing to the efforts of the university's Cambodian staff, who despite difficult conditions and low pay have given willing hands and hearts to the work of building the future.

\section{Two Years after the "Thaitanic"}

\section{Edward Vargo}

Edward Vargo has served as dean at Fu Jen University, Taipei, and Assumption University, Bangkok. Address: 66/51 Soi Sukumvit 33, Klongton, Klongtoey, Bangkok 10110, Thailand. Fax: 66-2-204-1158. E-mail: <evargo@loxinfo.co.th>.

A fter Thailand floated the baht on July 2, 1997, the basically bankrupt country had to request a $\$ 16.7$ billion loan from the International Monetary Fund. With negative growth of -9.4 percent in 1998, the economy is now expected to grow 3 to 4 percent in 1999. This past September, the government did not have to take the final installment of its IMF loan. Policy makers express guarded optimism that the economy is on the way to recovery, spurred on by a stable macroeconomic environment, improved investor sentiment, and successful implementation of key legal reforms. Even so, the recovery is slower than many had hoped. Huge non-performing loans currently stand at 45 percent of total lending for the entire financial system. While re-capitalization and massive debt restructuring continue, Thailand's real per capita GDP is not expected to return to the 1996 pre-crisis level of 70,000 baht until the year 2005 .

\section{Budget Cuts}

Within this context, higher education in Thailand has had to face its own challenges. Early attempts to institute budget cuts have continued with belt-tightening policies on the use of office supplies and utilities, organizing or attending conferences, and opening new courses. In some individual units of public universities, extra revenues from community service projects help to purchase badly needed equipment or offset the lack of central funds in other ways. However, only larger, more popular departments have such resources with which to support themselves.

According to Brother Simeon Anupatt P. Yuttachai, Vice-President for Financial Affairs at Assumption University, the crisis has demanded new projections of monthly cash flow in order to assure completion of its new campus, now in construction for over five years. Nothing has been scrapped in the original plans, but construction has slowed down to match possible monthly payments. The campus is still scheduled for a soft opening in June 2000, with fewer buildings completed. At other universities, like state-owned Srinakharinwirot, buildings under construction are being completed, but new construction that has already gained approval has been put on hold.

\section{Like most other universities, Assumption University declared a freeze on hiring last year.}

\section{Hiring Freezes}

Like most other universities, Assumption University declared a freeze on hiring last year. However, this policy is implemented with great flexibility so that departments under expansion may still hire additional full-time staff. State universities have a more rigid policy. Only 20 percent of the positions made available by retirement may be replaced, and the hiring freeze will stand until a new salary range for non-civil servants is set. Many have taken government incentives for early retirement in units like Ramkhamhaeng's Faculties of Law and Political Science, but the 20 percent replacement rate applies to the entire university rather than to individual units. As a result, the situation may become more labor-intensive for remaining lecturers because class sizes necessarily become larger. In departments that were overstaffed, however, the hiring freeze will not have so nega- 